\title{
Protein adsorption at solid surfaces: $A$ thermodynamic approach
}

\author{
Willem Norde \\ Department of Physical and Colloid Chemistry, Wageningen Agricultural \\ University, Post-box 8038 , 6700 EK Wageningen , The Netherlands
}

\begin{abstract}
Protein adsorption data are interpreted using thermodynamic arguments. Energetic and entropic contributions from the major sub-processes that constitute the overall adsorption process are presented.
\end{abstract}

\section{INTRODUCTION}

When an aqueous protein solution is exposed to a (solid) surface, spontaneous accumulation of protein molecules at the solid-liquid interface is generally observed. This phenomenon, referred to as protein adsorption, is of great relevance in a wide variety of natural and synthetic systems. The behaviour of proteins at interfaces is the net result of various types of interaction between the different components in the system, i.e., the protein molecules, the sorbent surface, the solvent (water) molecules and any other solutes present, such as lowmolecular-weight ions.

Irrespective of the mechanism, protein adsorption can only occur spontaneously (at constant pressure and temperature) if the Gibbs energy $G$ of the system decreases, that is, if

$$
\Delta_{\mathrm{ads}} \mathrm{G}=\left(\Delta_{\mathrm{ads}} \mathrm{H}-\mathrm{T} \Delta_{\mathrm{ads}} \mathrm{S}\right)<0
$$

where $H, S$ and $T$ are the enthalpy, entropy and temperature of the system, respectively, and where $\Delta_{\text {ads }}$ indicates the variation resulting from the adsorption process.

In this paper the major interactions that contribute to $\Delta_{\mathrm{ads}} \mathrm{G}$ will be discussed.

\section{ADSORPTION ISOTHERMS}

It is common to present adsorption data in so-called adsorption isotherms, where, at constant $T$, the amount of protein adsorbed $\Gamma$ is plotted against the protein concentration $c_{p}$ in solution. If the ascending branch (variation of $\Gamma$ with increasing $c_{p}$ ) coincides with the descending branch (variation of $\Gamma$ with decreasing $c_{p}$ ), the adsorption process is considered to be reversible with respect to variation in the proteln concentration. In that case the isotherm represents thermodynamic equilibrium and, hence, an equilibrium constant $K$ for the distribution of protein between the adsorbed and dissolved states can be evaluated. In turn, the standard Gibbs energy of adsorption $\Delta_{\mathrm{ads}} \mathrm{G}^{\circ}$ can be derived, according to

$$
\Delta_{\mathrm{ads}} \mathrm{G}^{\mathbf{0}}=-\mathrm{RT} \ln \mathrm{K}
$$

in which $R$ is the universal gas constant. The changes in the enthalpy and entropy follow from the influence of $T$ on the adsorption isotherms

$$
\Delta_{\mathrm{ads}} \mathrm{S}^{0}=-\frac{\partial \Delta_{\mathrm{ads}} \mathrm{G}^{\circ}}{\partial \mathrm{T}}
$$


and

$$
\frac{\Delta_{\mathrm{ads}} \mathrm{H}^{\circ}}{\mathrm{T}^{2}}=-\frac{\partial\left(\Delta_{\mathrm{ads}} \mathrm{G}^{\circ} / \mathrm{T}\right)}{\partial \mathrm{T}}
$$

However, with proteins, as with synthetic macromolecules, it is the rule rather than the exception that the ascending and descending branches of $\Gamma\left(c_{p}\right)$ do not coincide. As an example, data for the adsorption of bovine serum albumin (BSA) on glass are given in Fig. 1. As a consequence of the hysteresis, a thermodynamic description of the adsorption isotherm should be based on the laws of irreversible thermodynamics. In spite of this, many authors interpret protein adsorption data by applying reversible thermodynamics. The most common example of such an erroneous approach is the determination of $\Delta_{\mathrm{ads}} \mathrm{G}$ by fitting adsorption data to the Langmuir isotherm equation.

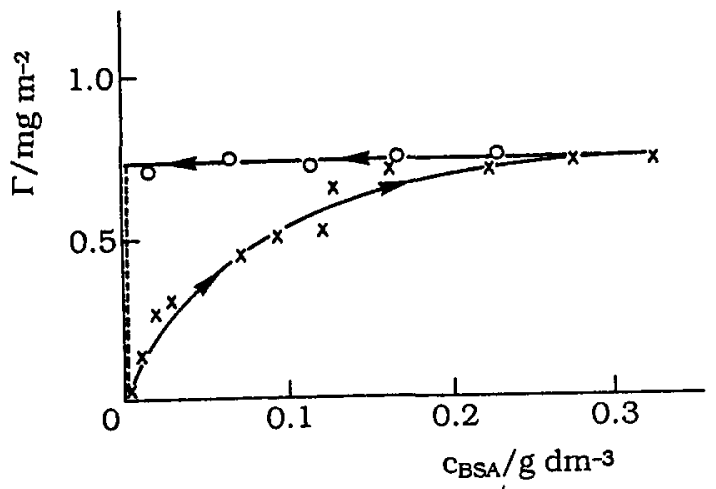

Fig. 1. Ascending and descending adsorption isotherms for serum albumin from aqueous solution on glass powder. Electrolyte: $0.05 \mathrm{M}$ phosphate buffer pH 7; temperature $25^{\circ} \mathrm{C}$.

The minimum error involved when treating protein adsorption as a reversible process can be estimated by calculating the entropy production in the irreversible process. In a closed system, the entropy change associated with any internal process, reversible or irreversible, can be written as

$$
\mathrm{dS}=\mathrm{Q} / \mathrm{T}+\mathrm{dS}_{\mathrm{ir}}
$$

where $Q$ is the heat exchange between the system and the surroundings and where $\mathrm{dS}_{\mathrm{tr}}$ is the entropy production. For a reversible process $\mathrm{dS}_{1 \mathrm{r}}=0$ (so that $\mathrm{dS}=$ $\left.\mathrm{Q}_{\mathrm{rev}} / \mathrm{T}\right)$ and for an irreversible change $\mathrm{dS}_{(\mathrm{r}}>0$. According to Everett (1) $\Delta_{\mathrm{ads}} \mathrm{S}_{(\mathrm{f}}$ cand descending $\left\{\Gamma\right.$ des $\left.\left(c_{p}\right)\right\}$ branches

$$
\Delta_{\text {ads }} S_{t r}=R \int \frac{\Gamma^{\text {asc }}\left(c_{p}\right)}{\Gamma^{\operatorname{des}}\left(c_{p}\right)} d \ln c_{p}
$$

Accurate solution of this integral requires detalled knowledge of the isotherms in the dilute $c_{p}$-region. Unfortunately, $c_{p}$-values çan not be detected below a certain limit. Taking a detectable limit of $0.002 \mathrm{~g} \mathrm{dm}^{-3}$ (using the Lowry method) it is for the BSA-glass isotherms shown in Fig. 1 inferred that $\Delta_{\text {ads }} S_{1 r}>20 \mathrm{~J} \mathrm{~K}^{-1}$ mol-1 $^{-1}$. It should be realised that if at $c_{p}<0.002 \mathrm{~g} \mathrm{dm}^{-3}$ the ascending and descending branches still do not coincide lwhich, in view of the shapes of the isotherms, is almost certain) the real value for $\Delta_{a d s} S_{i r}$ is far greater than $20 \mathrm{~J} \mathrm{~K}^{-1}$ mol-1. $^{-1}$.

\section{CALORIMETRY}

As a consequence of the irreversible nature of $\Gamma\left(c_{p}\right)$ a thermodynamic analysis of protein adsorption should be based on direct determination of $\Delta_{\mathrm{ads}} \mathrm{H}$ and $\Delta_{\mathrm{ads}} \mathrm{S}$. In view of the almost countless conformational and configurational changes that the protein, the solvent and other components may undergo upon adsorption, direct statistical determination of $\Delta_{\text {ads }} S$ is practically impossible. On the other hand, at constant pressure, $\Delta_{\text {ads }} \mathrm{H}$ equals the heat of adsorption, which can be measured calorimetry. 
At previous occasions we have reported enthalpy data for various protein-sorbent systems (2-5). In each of these studies $\Delta_{\mathrm{ads}} \mathrm{H}$ shows complex dependencies on parameters such as $\Gamma, \mathrm{pH}$ and $\mathrm{T}$. This may be illustrated by the curves in Fig. 2 , where $\Delta_{1} \mathrm{H}(\mathrm{pH})$ is shown for the adsorption of human serum albumin (HSA) from $0.05 \mathrm{M} \mathrm{RNO} 3$ aqueous solution onto various surfaces and under conditions where the isotherms attain their plateau-values.

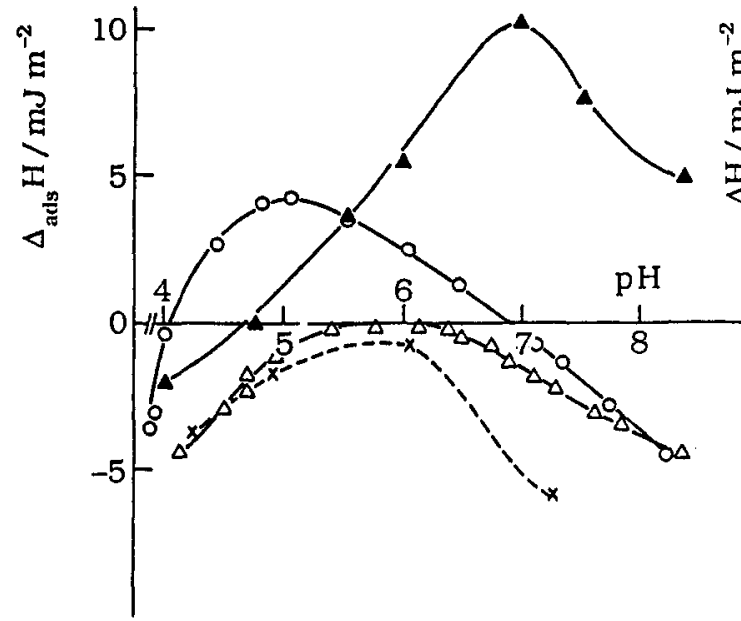

Fig. 2. Enthalpy of adsorption for serum albumin on various substrates, i.e. $(\Delta)$ negatively charged polystyrene $l \sigma_{0}=-2.3$

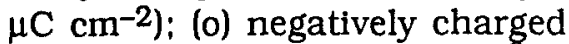
polystyrene $\left(\sigma_{0}=-15.5 \mu \mathrm{C} \mathrm{\textrm {cm } ^ { - 2 }}\right) ;(\Delta)$ positively charged polystyrene; (x) silver iodide. Electrolyte: $0.01 \mathrm{M} \mathrm{KNO}_{3}$; temperature $25^{\circ} \mathrm{C}$.

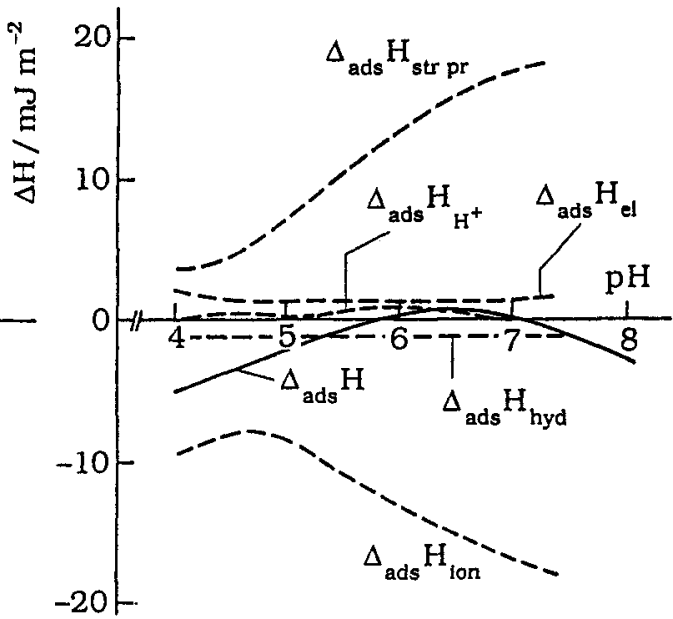

Fig. 3. Contributions from various subprocesses to the overall enthalpy of adsorption $\Delta_{\text {ads }} H$ for serum albumin on negatively charged polystyrene $\left(\sigma_{0}=\right.$ $-2.3 \mu \mathrm{C} \mathrm{cm}^{-2}$ ) in $0.05 \mathrm{M} \mathrm{KNO}_{3}$ aqueous solution. The subprocesses are discussed in the text.

The electrostatic potential of the protein varies with $\mathrm{pH}$, whereas those of the sorbent surfaces are essentially constant, and negative, over the $\mathrm{pH}$ range studied. If electrostatic interactions between the protein and the sorbent govern the adsorption process $\Delta_{\mathrm{ads}} \mathrm{H}$ would be an increasing function of $\mathrm{pH}$. If electrostatic interactions between the adsorbed protein molecules were dominating, a minimum in $\Delta_{\mathrm{ads}} \mathrm{H}(\mathrm{pH})$ should be found at the isoelectric point of $\mathrm{HSA}$. 1.e. at $\mathrm{pH}$ ca. 4.7. Neither one of these trends are observed, indicating that electrostatic interactions do not play a decisive role in HSA adsorption. On the contrary, adsorption still occurs spontaneously when the protein and the sorbent have the same charge sign and, as can be seen in Fig. 2, adsorption may even be exothermic under such conditions. This complex dependence indicates that no single type of interaction determines $\Delta_{\mathrm{ads}} \mathrm{H}$. As a consequence adsorption-enthalpy can only be interpreted if sufficient additional data concerning the mechanism of the overall adsorption process is available.

For HSA on polystyrene latices, Norde and Lyklema (6) have analysed $\Delta_{\mathrm{ads}} \mathrm{H}$ in terms of its contributions from a number of subprocesses. These subprocesses are: changes in the state of hydration of the sorbent surface (hyd); association/ dissociation of protons with charged groups on the protein surface $\left(\mathrm{H}^{+}\right)$; overlap of electric fields (el); non-electrostatic contribution to the incorporation of ions (other than protons) in the adsorbed layer (ion) and structural rearrangement in the protein molecule ( $\mathrm{str}$ pr). For a detailed discussion of this analysis is referred to references (5) and (6); here the main features are repeated briefly. The values for $\Delta_{\mathrm{ads}} \mathrm{H}_{\mathrm{H}^{+}}, \Delta_{\mathrm{ads}} \mathrm{H}_{\mathrm{el}}$ and $\Delta_{\mathrm{ads}} \mathrm{H}_{\text {Ion }}$ are estimated on the basis of proton titration data and electrokinetic measurements; those for $\Delta_{\mathrm{ads}} \mathrm{H}_{\mathrm{str}} \mathrm{pr}$ by subtracting the contributions from the other subprocesses from the calorimetrically determined value for $\Delta_{\mathrm{aqs}} \mathrm{H}$. The results, represented in Fig. 3 , show that $\Delta_{\mathrm{ads}} \mathrm{H}$ is largely determined by competition between $\Delta_{\text {ads }} \mathrm{H}_{10 p}$ and $\Delta_{\mathrm{ads}} \mathrm{H}_{\text {str }}$ pr. The values for $\Delta_{\text {ads }} \mathrm{H}_{\text {str }}$ are large and endothermic due to a loss of (secondary) structure in the protein molecule when it adsorbs on the sorbent surface. $\Delta_{\text {ads }} \mathrm{H}_{\text {str }} \mathrm{pr}(\mathrm{pH})$ reaches a minimum near the isoelectric point of the HSA/PS complex $\left(\mathrm{pH}^{2} \approx 3.9\right)$. This trend 
is in agreement with the general observation that under is̄oelectric conditions, where the native structure of the protein is maximally stable, $\Gamma_{\text {plateau }}(\mathrm{pH})$ is at a maximum (e.g. 6-10). The values for $\Delta_{\mathrm{ads}} \mathrm{H}_{\text {fon }}$ are large and exothermic due to hydrogen bond formation between water molecules upon the transfer of $\mathrm{K}^{+}$ions from water to the adsorbed layer. Cations are taken up in the low dielectric contact zone between the protein and the sorbent surface $(11,12)$ in order to prevent ac-cumulation of net charge and thereby development of a large electrostatic potential in this region (11). The enthalpy changes associated with the other subprocesses are relatively small. Such small values for $\Delta_{\mathrm{ads}} \mathrm{H}_{\mathrm{hydr}}$ are in agreement with experimental observation that (at $25^{\circ} \mathrm{C}$ ) hydrophobic dehydration is primarily determined by a large entropy increase (13) $\Delta_{\mathrm{ads}} \mathrm{H}_{\mathrm{H}^{+}}$is small because the protons that are used for protonation of the adsorbing protein molecules are provided by deprotonation of proteins remaining in solution. Finally, the small and relatively constant value for ${\mathrm{ads}_{\mathrm{ad}}}_{\mathrm{H}}(\mathrm{pH})$ suggest that protein-sorbent and lateral protein-protein interactions are largely screened by the co-adsorption of lowmolecular-weight-ions; this argument is supported by the dependency of ion coadsorption on $\mathrm{pH}(12)$.

As discussed in the foregoing section, derivation of $\Delta_{\mathrm{ads}} \mathrm{G}$ from adsorption isotherms is not possible. Hence, following the lines as for unravelling the adsorption enthalpy, we arrive at $\left(\Delta_{\mathrm{ags}} \mathrm{G}-\Delta_{\mathrm{ads}} \mathrm{G}_{\mathrm{str}} \mathrm{pr}\right)(\mathrm{pH})$. For the HSApolystyrene system Norde and Lyklema (5) found, under host conditions, positive values for ( $\left.\Delta_{\mathrm{ads}} \mathrm{G}-\Delta_{\mathrm{ads}} \mathrm{G}_{\text {str }} \mathrm{pr}\right)$. Because, for adsorption to occur spontaneously, $\Delta_{\text {ads }} \mathrm{G}$ must be negative, it implies that $\Delta_{\text {ads }} \mathrm{G}_{\text {str }}$ is is even more negative. It indicates that structure rearrangements in the protein molecules support the adsorption process. In the following section a procedure allowing a crude estimation $\Delta_{\text {ads }} \mathrm{G}_{\text {str }}$ pr will be discussed.

\section{PROTON TITRATION}

Proteins contain several acidic and basic groups. The net number of charged groups per protein molecule $Z_{\mathrm{H}}$ can be found from the proton titration curve $Z_{\mathrm{H}}(\mathrm{pH})$. In general, proton titrations of proteins are reversible For conditions of constant temperature and pressure, it can be derived that $(14,15)$

$$
G_{p r}\left(Z_{H}\right)=-2.303 R T \int_{z_{H}^{\circ}}^{z_{H}^{\prime}} p H\left(Z_{H}\right) d Z_{H}
$$
where $G_{p r}\left(Z_{\mathrm{H}}^{\circ}\right)$ is the Gibbs energy at an arbitrary reference state (usually $\mathrm{pH} 7$ and
$\left.25^{\circ} \mathrm{C}\right)$.

Figures $4 \mathrm{a}$ and $4 \mathrm{~b}$ show protein titration curves for hen's egg lysozyme (LSZ) and bovine milk $\alpha$-lactalbumin $(\alpha-\mathrm{LA})$. In each figure titration data for the proteins in both the dissolved and the adsorbed states are given. The titration curves are positioned with respect to a common reference point for each protein (16).

According to equation [7] $\mathrm{G}_{\mathrm{pr}}(\mathrm{pH})$ can be calculated by integrating the reciprocal titration curve (i.e. $\mathrm{pH}$ vs. $\left.\mathrm{Z}_{\mathrm{H}}\right)$. The Figs. $5 \mathrm{a}$ and $5 \mathrm{~b}$ give $\mathrm{G}_{\mathrm{pr}}(\mathrm{pH})$ for the dissolved and adsorbed $\mathrm{LSZ}$ and $\alpha \mathrm{LA}$, taking $\mathrm{G}_{\mathrm{pr}}\left(\mathrm{pH}_{\mathrm{H}} 7\right)$ of the dissolved protein as the reference point. The difference $\Delta_{\text {ads }} G_{p r} \equiv G_{p r}^{\text {ads }}-G_{p r}^{\text {diss }}$ reflects changes in the thermodynamic state of the protein resulting from the adsorption process. As a first approximation

$$
\Delta_{\text {ads }} G_{p r}=\left(\Delta_{\text {ads }} G_{p r}\right)_{\text {el }}+\left(\Delta_{\text {ads }} G_{\text {pr }}\right)_{\text {str pr }}
$$

where the subscripts el and str pr refer to changes in electrostatic interactions and to changes in the protein structure upon adsorption. Analysis of the titration curves (16) reveal that $\left(\Delta_{\mathrm{ads}} \mathrm{G}_{\mathrm{pr}}\right)_{\mathrm{el}}$ is relatively small for both proteins. It then follows that $\Delta_{\text {ads }} G_{p=}$ is mainly determined by $\left(\Delta a d s G_{p r}\right)_{s t r}$ pr. Thus, it can be judged from Figs. $5 \mathrm{a}$ and $5 \bar{b}$ that $\left(\Delta_{\mathrm{ads}} \mathrm{G}_{\mathrm{pr}}\right)_{\text {str } \mathrm{pr}}$ is much larger for $\alpha \mathrm{LA}$ than for LSZ.

Since $\left(\Delta_{\mathrm{ads}} \mathrm{G}_{\mathrm{pr}}\right)_{\text {str }}$ ard $\Delta_{\mathrm{ads}} \mathrm{G}_{\mathrm{str}}$ pr both refer to a Gibbs energy change resulting from structural rearrangements in the adsorbing protein molecules, the two quantities are assumed to be equivalent. 

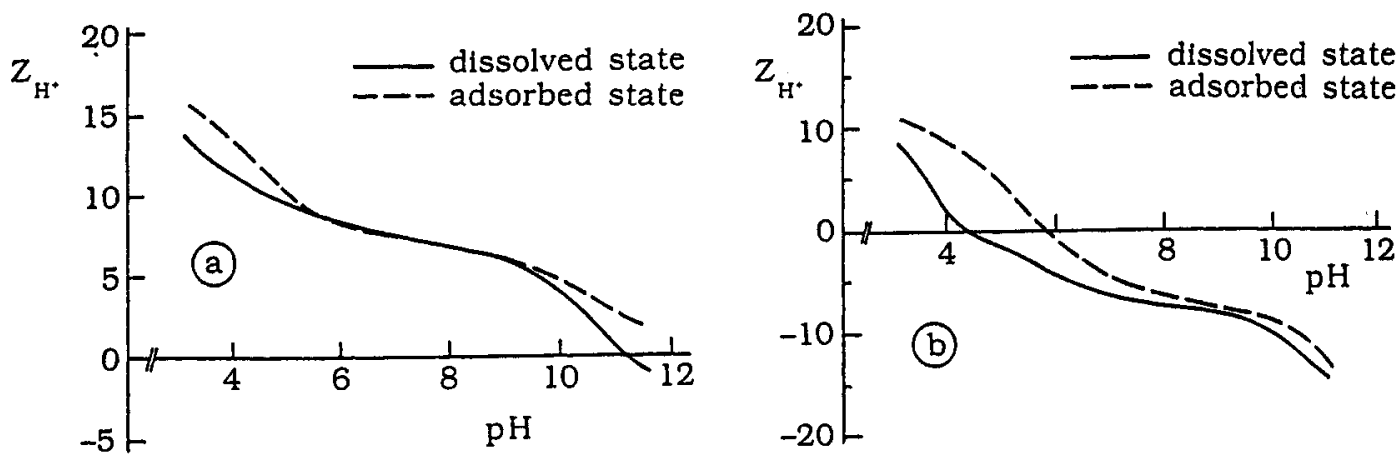

Fig. 4. Proton titration curves for (a) lysozyme and (b) $\alpha$-lactalbumin in aqueous solution and adsorbed to negatively charged polystyrene $\left(\sigma_{0}=-2.3 \mu \mathrm{C} \mathrm{cm}{ }^{-2}\right)$. Adsorption $\mathrm{pH}=7.0$. Electrolyte: $0.05 \mathrm{M} \mathrm{KCl}$; temperature $25^{\circ} \mathrm{C}$.
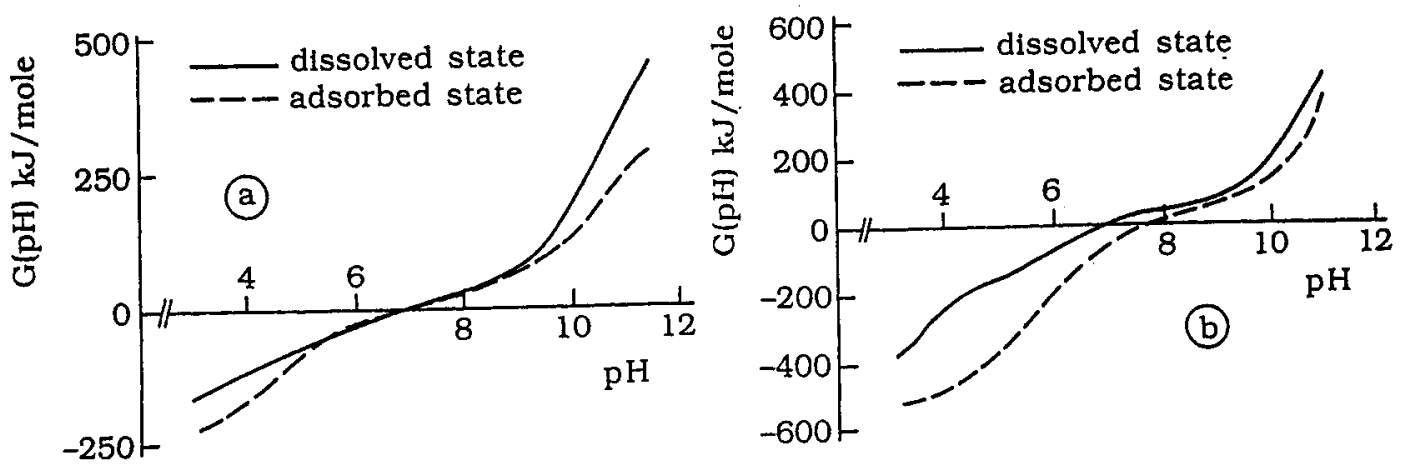

Fig. 5. Comparison of Gibbs energies as a function of $\mathrm{pH}$ for (a) lysozyme and (b) $\alpha$-lactalbumin in aqueous solution and adsorbed to negatively charged polystyrene latices. Conditions as in Fig. 4.

TABLE 1. Estimates of the contributions made by the subprocesses involved in protein adsorption on negatively charged polystyrene surfaces.

Conditions: plateau-adsorption; $0.05 \mathrm{M} \mathrm{KCl} ; 25^{\circ} \mathrm{C}$

\begin{tabular}{|c|c|c|c|c|c|c|}
\hline \multirow{3}{*}{$\begin{array}{l}\text { Overall protein } \\
\text { adsorption process }\end{array}$} & \multicolumn{3}{|c|}{$\begin{array}{l}\text { Lysozyme pH } 10 \\
\left(Z_{\mathrm{H}}=+5\right)\end{array}$} & \multicolumn{3}{|c|}{$\begin{array}{c}\alpha \text {-lactalbumin pH3 } \\
\left(\mathrm{Z}_{\mathrm{H}}=+12\right)\end{array}$} \\
\hline & \multicolumn{2}{|c|}{$\begin{array}{l}\Delta \mathrm{G} \quad \Delta \mathrm{H} \\
\left(\mathrm{kJ} \mathrm{mol}^{-1}\right)\end{array}$} & \multirow{3}{*}{$\frac{\stackrel{\Delta S}{\left(\mathrm{KJ} \mathrm{K}^{-1} \mathrm{~mol}^{-1}\right)}}{0.64}$} & \multirow{2}{*}{$\begin{array}{c}\Delta G \\
(k J \\
-400\end{array}$} & \multirow{2}{*}{$\frac{\Delta \mathrm{H}}{-20}$} & \multirow{3}{*}{$\frac{\begin{array}{c}\Delta S \\
\left(\mathrm{~kJ} \mathrm{~K} \mathrm{~K}^{-1}\right.\end{array}}{1.28}$} \\
\hline & -280 & -90 & & & & \\
\hline subprocesses: & & & & & & \\
\hline $\mathrm{H}^{+}$association & -20 & 0 & 0.07 & -40 & 0 & 0.14 \\
\hline $\begin{array}{l}\text { overlap of electric } \\
\text { fields }\end{array}$ & -10 & -20 & -0.03 & 20 & 30 & 0.03 \\
\hline $\begin{array}{l}\text { non-electrostatic } \\
\text { ion medium change }\end{array}$ & 30 & -80 & -0.37 & 40 & -60 & -0.67 \\
\hline $\begin{array}{l}\text { sorbent surface } \\
\text { dehydration }\end{array}$ & -220 & -40 & 0.60 & -220 & -40 & 0.60 \\
\hline $\begin{array}{l}\text { rearrangements in the } \\
\text { protein structure }\end{array}$ & $-60 \pm 30$ & 50 & $0.37 \pm 0.20$ & $-200 \pm 50$ & 150 & $1.18 \pm 0.20$ \\
\hline
\end{tabular}




\section{THERMODYNAMIC ANALYSIS OF THE PROTEIN ADSORPTION PROCESS}

Following the procedures explained in the foregoing sections, the contributions from the various subprocesses to $\Delta_{\mathrm{ads}} \mathrm{H}$ and $\Delta_{\mathrm{ads}} \mathrm{G}$ can be estimated. The corresponding entropy effects follow from $\Delta S=\left(\Delta \mathrm{H}^{\mathrm{a}}-\Delta \mathrm{G}\right) / \mathrm{T}$. Table 1 summarises the results of such an analysis for the adsorption of LSZ and $\alpha \mathrm{LA}$ from an aqueous $0.05 \mathrm{M} \mathrm{KCl}$ solution onto negatively charged polystyrene surfaces $(4,15)$.

The overall Gibbs energies of adsorption are large and negative for both proteins, for $\alpha$ LA even more so than for LSZ. They are primarily the result of an increase in entropy. Dehydration of the hydrophobic polystyrene surface is the major contributing subprocess. A remarkable result is the difference between the effects from structure rearrangements in LSZ and $\alpha \mathrm{LA}$, respectively. It indicates that structural changes upon adsorption are more severe in $\alpha \mathrm{LA}$ than in LSZ. This conclusion is supported by micro-differential scanning calorimetry using the same systems (4). The results are also consistent with earlier reports $(3,17-20)$, where it has been concluded that the adsorption of LSZ is governed by electrostatic and (de)hydration processes, whereas with $\alpha \mathrm{LA}$ changes in the protein structure, leading to an increased conformational entropy, is a major driving force for adsorption.

\section{REFERENCES}

1. D.H. Everett, Trans. Faraday Soc. 50, 1077 (1954).

2. W. Norde, and J. Lyklema, J. Colloid Interface Sci. 66, 295 (1978).

3. P.G. Koutsoukos, W. Norde and J. Lyklema, J. Colloid Interface Sci, 95 . 3854(1983).

4. T. Arai and $W$. Norde, Colloids and Surfaces 51,1 (1990).

5. C.A. Haynes and $W$. Norde, J. Colloid Interface Sci., to be submitted (1993).

6. W. Norde and J. Lyklema, J. Colloid Interface Sci. 71, 350 (1979).

7. B.W. Morrissey and R.R. Stromberg, J. Colloid Interface Sci. 46, is2 (1974).

8. W. Norde and J. Lyklema, J. Collold Interface Sci. 66, 257 (1978).

9. P. Bagchi and S.M. Birnbaum, J. Colloid Interface Sci. 83, 460 (1981).

10. A.V. Elgersma, R.J. Zsom, W. Norde and J. Lyklema, Colloids and Surfaces 54. 89 (1991).

11. W. Norde and J. Lyklema, J. Colloid Interface Sci. 66, 285 (1978).

12. P. van Dulm, W. Norde and J. Lyklema, J. Colloid Interface Sci. 82, 77 (1981).

13. C. Tanford, "The Hydrophobic Effect", Wiley-Interscience, New York (1973).

14. W. Pfell, and P.L. Privalov, Blophys. Chem. 4, 23 (1976).

15. W. Norde and J. Lyklema "Proton Titration and Electrokinetic Studies on Adsorbed Protein Layers" in "Surface and Interfacial Aspects of Biomedical Polymers" T.D. Andrade Ed., (1985).

16. C.A. Haynes, $E$. Sliwinski and W. Norde, J. Colloid Interface Sci., to be published, (1993).

17. W. Norde and J. Lyklema, J. Blomater. Sci. Polymer Edn. 2, 183 (1991).

18. W. Norde, T. Arai and $H$. Shirahama, Biofouling 4,37 (1991).

19. W. Norde and J.P. Favier, Colloids Surfaces 64, 87 (1992).

20. W. Norde and A.C.I. Anusiem, Colloids Surfaces 66, 299 (1992). 